\title{
PE-049.09
}

Mr. B. D. Stewart, Conmissioner of Mines

Terrltorfal Department of Mines

P.O. Box 2811

Juneau, Alaska

February 25, 1948

\section{FIELD TRIP-LIVENGOOD}

Dear Mr. Stewart:

At the spectal Invitation of Mr. D. C. Beyer, Manager of Livengood Placers, Inc.. 1 made a fleld trip to Lfvengood to inspect the company operations there. As a spectal courtesy to the Department of Mines my transportation and other expenses were borne by the company.

I left Falrbanks Sundaymorning. February 21 st and returned on Tuesday morning, February 24th. While at LIvengood I had a very pleasant v1sit with Mr. Beyer and we discussed the many problems confronting his company. At the present time Livengood Placers, Inc., is repairing the damage suffered to their tunnel as a result of the break which occurred at the intake last summer. The total extent of the damage is not known and will not be known until they complete the sinking of a 110 foot shaft at a point mid-way on the tunnel. JApproximately 200 feet of wood stave pipe was damaged near the intake and this is being replaced with steel plpe.

The tunnel which is 2800 feet long is in frozen gravel and timbered throughout. A 42" "red" wood stave pipe conveys the water from the reservolr, on the Hess Creek water shed, to the Livengood Creek drainage thence down a dftch to the present s1ta of operations. When the water broke through from the reservoir about $200^{\circ}$ of the tunnel was caved near the Intake and considerable gravel was washed into the lower section of the tunnel. The wood stave pipe near the Intake was damaged but the remaining plpe is still intact and is open and free of any obstruction. However, the tunnel is not accessfble due to the excessive amount of gravel plled alongside of the outside of the pipe. When the shaft is sunk they hope to be able to clean out the gravel and then ascertain if any serfous damage has been done to the square sets and lagging.

The damage to the tunnel has impaired the progress of their operations constderably and is a serlous blow. It is doubtful if they wlil be able to conduct very extensive 
operations durlng the coming season. The Livengood Placers, Inc., have had many setbacks during the past years without the benefit of much production.

At the present tine Livengood Placers, Inc., is under obligation to the R.F.C. for over $\$ 2,500,000$. With this principle bearing an interest rate of $4 \%$ there is much to be retired before proftts are realized by the stockholders.

During the past year Livengood Placers, Inc., revalued a portion of thetr reserves Wh the following resulis:

$$
\begin{array}{cl}
20,000,000 & \text { cubic yards of muck } \\
10,000,000 & \text { cublc yards of dredge section } \\
7,300,000 & \text { Total value } \\
73 \$ & \text { average value a cublc yard dredge section }
\end{array}
$$

They estimate that they can strip for $6 \pm$ a cubic yard, thaw for $10 \%$ a cublc yard, and dredge for 204 a cuble yard; a sumation on the basis of these costs is as follows:

$$
\begin{array}{ll}
\$ 1,200,000 & \text { muck } \\
1,000,000 & \text { thawing } \\
-\frac{2,000,000}{4,200,000} & \text { dredging }
\end{array}
$$

The above flgures are hlghly confidentlal and will be respected by the Department of Mines. I made a study of the computations of these reserves at the time I visfted the operations and the figures that I quote are quite accurate.

At the present time there are about 25 men employed on the project; these inen are engaged in repairing the tunnel. I did not observe any unsafe labor practices or hazardous conditions while at the property. My actual visit at the tunnel was quite short but observations for unsafe conditions were first in mind.

I am not requistitioning for travel. allowance inasmuch as transportation and board was furntshed whlle away from headquarters.

With kindest peroonal regards I remain

\author{
Yours very truly, \\ Bruce I Thomas \\ Department of Mines \\ College. Aleska
}

